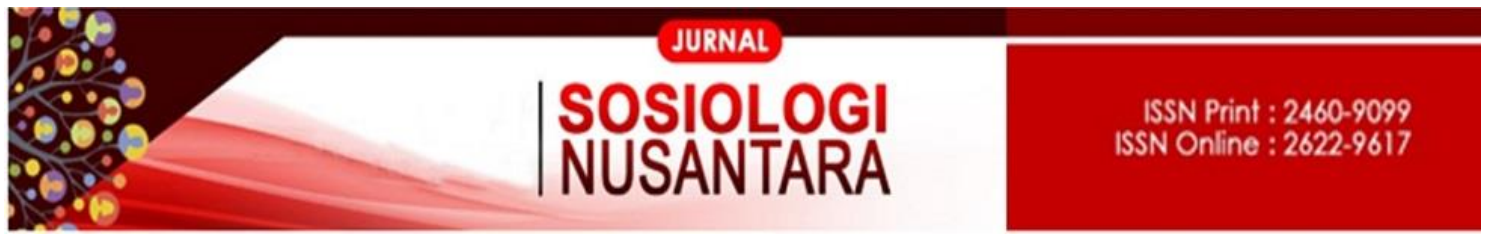

https://ejournal.unib.ac.id/index.php/jsn

DOI ://doi.org/10.33369/jsn.5.1.1-21

\title{
MAKNA TARI NAPA PADA BIMBANG ADAT SUKU SERAWAI DI KOTA MANNA KABUPATEN BENGKULU SELATAN
}

\author{
THE MEANING OF NAPA DANCE IN TRADITIONAL BIMBANG \\ OFSERAWAI ETNICS IN MANNA CITY,SOUTH BENGKULU REGENCY
}

\author{
Dwi Septi Fitriani \\ dwiseptifitriani798@gmail.com
}

Fakultas Ilmu Sosial dan Ilmu Politik, Universitas Bengkulu

\begin{abstract}
Abstrak
Tari Napa merupakan salah satu tarian adat yang berasal dari suku Serawai.Penelitian ini bertujuan untuk mengetahui makna simbolik yang terkandung dalam setiap rangkaian tari Napa.Penelitian ini menggunakan metode penelitian deskriptif kualitatif dengan menggunakan Teori Interaksionisme Simbolik.Pengumpulan data dalam penelitian ini menggunakan teknik wawancara, observasi dan dokumentasi.Selanjutnya analisis data menggunakan reduksi data, analisis data dan penarikan kesimpulan.Tari Napa dimulai dengan bedindang, diiringi dengan jundai serta alat musik serunai dan rebana, maknanya yaitu akan menyatukan keluarga dengan orang baru sehingga membentuk keluarga baru. Gerakannya antara lain, gerak besembah maknanya penari memiliki sikap yang rendah diri dan menghormati. Mecah langkah, maknanya adalah mengembangkan langkah dalam kebaikan.Gerakan tangan (ngancam, nangkap, dan ngunci) maknanya sebagai perlindungan diri, dan bejabatan tangan bermakna damai. Kemudian, saat menari ada lengguai yang diletakkan di atas tikar .Lengguai bagi suku Serawai dianggap sebagai raja adat. Kemudian, tikar yang diletakkan seperti tanda tambah atau bersilang memiliki makna pertemuan antara dua keluarga besar yang akan bersatu menjadi keluarga baru. Makna dari tari Napa bagi masyarakat adalah sebagai tanda menghormati para pemimpin negeri atau yang sedang diagungkan saat itu. Selain itu pula, saat penyambutan tamu kehormatan biasanya masyarakat akan berkumpul sehingga dapat memberikan makna kekompakan bagi masyarakat dalam menjaga keutuhan dan kesatuan adat istiadat, kesenian serta budaya Serawai.
\end{abstract}

Kata Kunci : Makna Simbol, Tari Napa

\begin{abstract}
Napa dance is one of the traditional dances originating from Serawai etnic. This research aimed at discovering the symbolic meaning of every Napa dance stages. The method of the research is descriptive qualitative by using symbolic interactionalism. The data collection techniques are interview, observation, and documentation. In addition, the data analysis techniques is data reduction, data analysis, and conclusion
\end{abstract}




\section{I Dwi Septi Fitriani}

Makna Tari Napa Pada Bimbang Adat Suku Serawai Di Kota Manna .......

drawing. Napa dance is started with bedindang followed by jundai as well as serunai and rebana traditional musical instruments. The meaning is it will unite the family to new people to become a new family. The movements are besembah which means the dancer is friendly and respectful. Mecah langkah which means to spread the steps for goodness, the movements of hands (ngancam, nangkap, and ngunci) which means the self-protection, and bejabatan hand which means peace. Moreover, while dancing there is lengguai on the rug that people consider as the king of tradition. Next, the rug which is arranged into cross or plus sign means two families from different background will unite as a new big family. All in all, the meaning of Napa dance for society is the symbol of respecting the elders and leaders of country. Finally, when the guests are being welcomed, people will gather which will show the solidarity of preserving cultures, art and traditions.

Keywords: Meaning of Symbol, Napa Dance

\section{PENDAHULUAN}

Kota Manna, Kabupaten Bengkulu Selatan dihuni oleh penduduk aslinya yaitu suku Serawai. Suku Serawai memiliki kesenian tradisional yang berperan penting dalam kehidupan bermasyarakatnya.Salah satu kesenian tradisional yang sampai sekarang masih ada pada masyarakat suku Serawai dan sekaligus sebagai ciri khas tari tradisional masyarakat Serawai adalah tari Napa.Tari Napa ada 2 (dua) jenis yaitu pertama tari Napa yang menggunakan pedang atau pisau yang asli bukan properti yang disebut dengan tari Rendai, dan kedua tari Napa tangan kosong.Fokus penelitian ini adalah tari Napa tangan kosong. Namun, antara tari Rendai dan tari Napa tangan kosong mempunyai gerakan yang sama. Tari Napa diciptakan sebagai tari tradisional dari kebiasaan masyarakat setempat yaitu berkumpul dan mempelajari pencak silat namun tarian dalam "tari Napa" ditampilkan oleh para laki-laki saja dalam bimbang adat suku Serawai sebab gerakan pada tari Napa sangat tegas seperti silat. Kostum yang digunakan dalam tari Napa adalah kostum tradisional adat Serawai yaitu pakaian raja sehari yaitu pakaian pengantin laki-laki yaitu celana panjang dasar, kain songket pengantin, baju kemeja panjang warna putih disertai jas hitam dan kopiah pengantin atau jika tidak ada boleh dengan celana panjang, baju kemeja panjang dilengkapi jas, kain sarung dan kopiah. Selain kostum ada penari dan pemusik yang menjadi bagian penting dalam tari Napa.

Tari Napa ini sudah jarang diadakan karena sudah masuknya budaya modern seperti organ tunggal yang mulai menjiwa di masyarakat Kota Manna.Namun di Kota Manna sebenarnya ada sanggar tari adat Serawai namanya Sanggar Maju Jaya yang 
didirikan oleh mendiang Alm.datuk AM, beliau merupakan kerabat dari bapak IN yang juga merupakan pelatih utama atau istilahnya adalah guru agung semasa hidupnya di Kota Manna, meskipun saat ini Sanggar Maju sudah jarang aktif karena sudah kekurangan orang untuk mempertahankannya sepeninggal guru agung Alm. datuk AM atau bisa dikatakan sanggar ini hampir mati tergantikan oleh budaya baru yaitu organ tunggal. Menurut bapak IN pelaku tokoh adat Serawai yang juga merupakan pengurus Sanggar Maju Jaya yang memang berdasarkan turun-temurun keluarganya merupakan para tetua adat Serawai di Kota Manna mengatakan bahwa bubarnya Sanggar Maju Jaya sampai kekurangan orang dalam mempertahankan sanggar ini ialah semenjak guru agung Alm. datuk AM meninggal semangat berkumpul para anggota sanggar sudah tidak ada lagi selain pada saat akan mengadakan acara saja. Sanggar Maju Jaya ini biasanya melakukan latihan-latihan seperti latihan bedindang, latihan mencak, dan latihan bekelintang.

Dalam tarian Napa meskipun sanggar ini sudah hampir mati tetapi latihan-latihan seperti mencak tetap bisa dilaksanakan ketika ada permintaan dari suatu pihak yang mengadakan acara. Menurut bapak YB selaku ketua Badan Musyarawah Adat di Kota Manna, Kabupaten Bengkulu Selatan mengatakan bahwa biasanya ketika tarian Napa ini dilakukan paling sedikit 2 (dua) pasang penari Napa dan paling banyak 4 (empat) pasang penari Napa yang tampil. Tari Napa sendiri dilakukan untuk menyambut orangorang besar seperti bupati, gubernur dan orang-orang terhormat lainnya seperti raja dan ratu sehari.Raja dan ratu sehari sepasang calon pengantin, raja dan ratu adalah sebutan bahasa Serawai.Sebelum tari Napa dimulai oleh para penari atau pendekar atau kesatria terlebih dahulu diawali dengan bedindang.Bapak MU yang merupakan salah satu penari Napa menyatakan bahwa bedindang adalah salah satu syarat untuk melaksanakan tari Napa, sebelum bedindang dilaksanakan maka tari Napa tidak boleh dimulai.Oleh karena itu, tari Napa dilaksanakan setelah bedindang atau memukul alat musik rebana oleh suatu sanggar seperti Sanggar Maju Jaya.Penelitian mengenai tari Napa pernah dilakukan oleh Junita (2013).Namun penelitian tersebut hanya melihat tentang keberadaan tari Napa di kehidupan masyarakat Serawai sekarang, tanpa melihat makna dan simbol yang ada pada tari Napa.

Berdasarkan penjelasan uraian yang dipaparkan, peneliti ini secara khusus menggali mengenai makna tari Napa pada bimbang adat suku Serawai dalam setiap 
4 I Dwi Septi Fitriani

Makna Tari Napa Pada Bimbang Adat Suku Serawai Di Kota Manna .......

episode-episode tariannya yang dimulai dari makna gerakan, makna kostum dan makna musik yang disajikan dalam Tari Napa.Penelitian ini menggunakan metode penelitian sosial yaitu metode penelitian kualitatif deskriptif.Metode ini berupaya untuk mengidentifikasi tentang bagaimana makna tari Napa tangan kosong pada bimbang adat suku Serawai di Kota Manna, Kabupaten Bengkulu Selatan?

\section{METODE PENELITIAN}

Penelitian ini menggunakan pendekatan kualitatif deskriptif, yang merupakan metode dalam penelitian sosial.Metode penelitian kualitatif juga merupakan sebuah metode penelitian yang memandang realitas sosial sebagai suatu kesatuan yang utuh, kompleks, dinamis dan penuh makna. Penelitian dilakukan pada objek yang alamiah dan berkembang apa adanya tanpa ada manipulasi dan campur tangan peneliti. Dalam penelitian kualitatif, peneliti merupakan instrumen utama (human instrument) sedangkan teknik pengumpulan data dilakukan secara trianggulasi (gabungan). Analisis data bersifat induktif berdasarkan data yang ditemukan dilapangan agar mendapatkan data yang memiliki makna (Sugiyono, 2012: 34). Penelitian ini dilakukan dengan menggunakan pendekatan kualitatif bermaksud untuk mengidentifikasi makna simbolik tari Napa pada bimbang adat suku Serawai, sehingga diharapkan dapat memberikan pengetahuan dan pengokohan pengetahuan terhadap makna simbolik tari Napa bagi

masyarakat Serawai maupun masyarakat umumnya di Kota Manna, Kabupaten Bengkulu Selatan pada bimbang adat suku Serawai, dan juga diharapkan sebagai sumbangan pemikiran bagi pelestarian, pengembangan, dan pemberdayaan kesenian tarian tradisional suku Serawai agar dapat meningkatkan apresiasi masyarakat terhadap kesenian tradisional.

\section{PEMBAHASAN}

Informan penelitian ini adalah penari, pemusik dan tokoh adat. Ada beberapa hal mengenai makna simbolik yang terkandung dalam tari Napa, yaitu:

\section{Makna Dari Rangkaian Pelaksanaan Tari Napa}

Menurut bapak YB selaku Ketua Badan Musyawarah Adat Kota Manna, Kabupaten Bengkulu Selatan pelaksanaan tari Napa dilaksanakan dengan rangkaian sebagai berikut: 


\section{- Perembak}

Pertama kali yang dilakukan masyarakat suku Serawai sebelum mereka melaksanakan pernikahan yaitu mengenal perembak (sifat dan karakter). Biasanya calon raja sehari datang ke rumah calon ratu sehari untuk bertemu dengan calon ratu sehari dan berkenalan lebih dekat dengan keluarga calon ratu sehari dan terlebih dahulu diterima oleh orang tua sang calon ratu sehari dan sang calon raja sehari harus pandai merayu orang tuanya dengan bahasa yang halus "perembak" dan memperlakukan orang tuanya dengan sebaik-baiknya agar hati orang tua sang calon ratu sehari menerima kedatangan bujang tersebut. Tetapi apabila sang calon raja sehari tidak sopan terhadap orang tua sang calon ratu sehari maka mereka tidak akan senang dengan kedatangan bujang.

\section{- Betunangan}

Setelah selesai tahap awal perkenalan antara laki-laki dan perempuan atau mengenali perembak satu sama lain, kemudian berlanjut pada keluarga kedua belah pihak untuk menjalani proses betunangan.Betunangan artinya bertukar cincin dan dilakukan sebelum akad nikah dan juga sebelum betunangan tentunya ada yang namanya antaran. Biasanya dalam prosesi antaran ini, calon raja sehari dan rombongan (mendah) akan datang pada waktu yang telah ditentukan. Apabila pihak keluarga calon raja sehari yang akan meminang calon ratu sehari setuju akan jumlah uang atau benda antaran maka kedua belah pihak memberitahukan kepada ketua adat/lurah/kepala desa dan penghulu yang secara resmi akan melaksanakan pengantaran uang atau mengantar uang. Setelah selesai acara betunangan dan telah disepakati kapan hari akan dilangsungkan pernikahan, maka calon raja sehari sujud sembah atau bersalaman kepada seluruh hadirin, yang dimulai dari kedua orang tua calon ratu sehari dan dilanjutkan kepada ketua adat/lurah/kepala desa serta seterusnya kepada adiak sanak. Maknanya sebagai tanda perkenalan dari calon raja sehari yang akan duduk di singgah sana atau pelaminan. Kemudian terakhir, pada acara ini pula juga dilakukan pengantian nama, maksudnya pergantian nama panggilan atau tutughan.

\section{- Tutughan}

Setelah mereka betunangan mereka pun melakukan pergantian nama disini maksudnya pergantian nama panggilan atau tutughan. Dimaksudkan agar tata cara bicara panggilan lebih halus dan lebih baik dan lebih enak didengar di lingkungan 
6 I Dwi Septi Fitriani

Makna Tari Napa Pada Bimbang Adat Suku Serawai Di Kota Manna .......

setempat. Pergantian nama panggilan ini terjadi setelah selesai acara betunangan bisa ditentukan apakah dan siapakah panggilan yang cocok. Contoh dari tutughan tersebut adalah misalkan kakak pertama dari si gadis dipanggil bukan kakak melainkan dang, sedangkan bila kakak dari ayah ratu sehari dipanggil dengan sebutan uwak.Hal tersebut dilakukan supaya lebih sopan, karena memang turun temurun seperti itu yang dilakukan oleh suku Serawai. Kemudian setelah melaksanakan tata cara tadi maka masuklah ke acara merempah adiak sanak sampai acara terakhirnya yaitu bimbang adat.

\section{- Beijau}

Setelah selesai tahapan-tahapan yang diawali dengan perkenalan antara calon raja dan ratu sehari atau mengenali perembak satu sama lain, betunangan dan tutughan. Kemudian berlanjut pada keluarga kedua belah pihak untuk menjalani proses pernikahan, ada satu prosesi yang sangat penting dan sarat akan makna yaitu proses beijau. Beijau berasal dari bahasa Serawai yang artinyamusyawarah mufakat, yang terjadi antara keluarga besar kedua belah pihak yang akan melangsungkan pernikahan, ketua adat/lurah/kepala desa serta masyarakat. Dalam adat pernikahan suku Serawai beijau ini sangat penting dan dijadikan sebagai awal dari prosesi pernikahan. Tidak akan terjadi pernikahan tanpa adanya beijau antara kedua belah pihak keluarga yang akan menikah.Beijaubiasanya dilakukan pada malam hari sehabis Isya' setelah ada penjeghuman untuk kaum bapak-bapak dari pihak keluarga baik dari calonraja maupun ratu sehari.Sebelum melaksanakan acara beijau, di siang harinya kaum ibu-ibu gotongroyong masak lupis.

Seminggu sebelum masak lupis, biasanya baik ibu dari calon raja maupun ratu sehari atau keluarganya melakukan penjeghuman terlebih dahulu, yang bertujuan untuk mengajak kaum ibu-ibu sekitar lokasi acara untuk masak lupis.Lupis adalah makanan khas suku Serawai yang terbuat dari beras ketan yang dimasukkan ke dalam daun kelapa yang sudah dibentuk menjadi segitiga kemudian dimasak seperti memasak ketupat, dan dihidangkan bersama kuahnya yang terbuat dari gula aren dan santan saat beijau.Beijau dilakukan di dalam suatu ruangan yang terdiri dari para bapak yang disebut dengan majelis. Alasan dilakukannya beijau oleh para bapak adalah karena suku Serawai menganut garis keturunan patriaki sehingga suatu adat masyarakat yang mengatur alur keturunan berasal dari pihak ayah. 
Di dalam majelis peserta harus memakai kain sarung, celana panjang dasar berwarna hitam, baju kemeja dan jas.Jika tidak memakai pakaian seperti itu maka peserta tidak boleh masuk ke dalam majelis.Beijau yang dilakukan dengan sesama orang Serawai tentu berbeda jika dilakukan dengan orang yang berbeda suku. Berdasarkan hasil observasi di lapangan, beijau itu adalah musyawarah mufakat untuk mendapatkan kesepakatan antara kedua belah pihak keluarga yang akan melangsungkan pernikahan. Masyarakat berpandangan jika beijauini perlu tetap dilakukan meski mendapatkan calon menantu pendatang atau dari luar daerah Bengkulu.Makna dari adat beijau bagi mereka sangatlah penting, hal itu terlihat dari bagaimana akhirnya mereka menemukan kesepakatan mengenai pelaksanaan pernikahan antara kedua anak atau keponakan atau cucu mereka.Beijau dapat dikatakan sebagai sarana dalam mempertahankan nilai-nilai adat Serawai.nilai dan norma-normanya dengan cara mewariskannya dari generasi ke generasi. Sebab salah satu karakter budaya adalah berupaya mempertahankan eksistensi nilai-nilai dan norma-normanya dengan cara mewariskannya dari generasi ke generasi. Dari segi pelaksanaannya beijau dilakukan dihadapan ketua adat, yang mengisyaratkan untuk menyatukan kedua pihak keluarga yang disimbolkan beijau tersebut disetujui oleh ketua adat.

\section{- Merempah Adiak Sanak}

Dalam adat Suku Serawai peresmian pernikahan dilakukan di rumah keluarga perempuan terlebih dahulu, karena di rumah calon ratu sehari biasanya upacara pernikahan dilangsungkan.Rangkaian upacara pelaksanaan pernikahan dalam adat Suku Serawai disebut bimbang adat dengan berbagai persiapan seperti negak pengujung/negak belabar atau tarub, akad nikah sampai ke pesta pernikahannya.Sebelum negak pengujung/belabar terlebih dahulu adiak sanak bersama masyarakat bergotong-royong mendirikan tarub dalam kurun waktu sehari sebelum negak pengujung/belabar.Tarub adalah tenda sementara beratapkan terpal ditempat dilangsungkannya seluruh upacara pernikahan yaitu di rumah calon ratu sehari.Rangkaian acara tarub dari meghampai batan gulai sampai dengan masak segala macam keperluan acara di hari itu. Biasanya pada acara inilah akad nikah akan dilangsungkan yaitu dirumah calon ratu sehari. Sebelum calon raja sehari dan rombongan masuk kerumah ratu sehari terlebih dahulu disambut oleh tuan rumah dengan sejenis pantun yang dilantunkan seperti nyanyian yang disebut jundai, kemudian 
disusul dengan tarian Napa dan sebelumnya dari kedua belah pihak sudah menyiapkan penari masing-masing yang akan menari Napa baik dengan tangan kosong, dengan pisau duau ataupun dengan pedang. Dalam penelitian ini adalah tangan kosong dan gerakannya pun sama artinya tidak ada yang membedakan antara tangan kosong dengan yang memakai pisau duau atau memakai pedang.

Kemudian, apabila setelah melaksanakan tari Napa, mulailah para tetuah dari kedua belah pihak mempelai menari, calon raja dan ratu sehari pun ikut menari, yang sebelumnya telah dilaksanakannya bedindang. Setelah mereka menari tari Napa yang bertujuan untuk menyambut calon raja sehari dan rombongan yang baru datang, ini menyimbolkan bahwa kemeriahan akan segera dimulai, biasanya hal ni dilakukan ketika sebelum calon raja sehari masuk ke dalam rumah calon ratu sehari untuk melakukan akad nikah disaksikan oleh sanak saudara.

\section{- Adat Bejundai}

Dalam pelaksanaan tari Napa ada orang yang menyanyikan pantun dengan bersyair yang dikenal dengan sebutan jundai. Jundai biasanya terdapat 1 (satu) orang pria, tetapi ada juga yang 2 (dua) orang yang berasal dari pihak raja sehari dan pihak ratu sehari untuk berbalas pantun.Menurut bapak ME dan bapak MA pantun-pantun yang dibawakan memiliki kategori yaitu, ngensian (meninggikan derajat seseorang), mujikah (memuji seseorang) dan ngetaui (mencaci seseorang).

Pantun pertama:

Makan sirih berpinang tidak

Pinang adau di gunung batu

Lihat di kiri di kanan tidak

Terasau badan umang piatu

Pantun kedua:

Anak ikan di makan ikan

Anak tengiri di dalam laut

Sanak bukan saudara bukan

Karna budi tersangkut paut

Berikut terjemahan pantun yang berbahasa Serawai kedalam bahasa Indonesia. Terjemahannya adalah sebagai berikut ini:

Pantun pertama:

Makan sirih tidak pakai pinang

Pinangnya ada di gunung batu

Tidak melihat di kiri dan di kanan

Terasa badan anak piatu 
Pantun Kedua:

Anak ikan dimakan ikan

Anak tenggiri di dalam laut

Sanak bukan saudara bukan

Karena budi tersangkut paut

Sedangkan menurut bapak YB pantun yang sering dipakai selain 2 (dua) buah pantun tersebut, dengan berbunyi "ayiiii, oiiii, dapek di dapek, oiii yu dibuatkah ngucapkah terimau kasiah" artinya "ayiii, oiii, dapat di dapat, oiii yang dilaksanakan ini cara mengucapkan terima kasih" sambil diucapkan berulang-ulang sampai penari selesai menari. Pelaksanaan tari Napa selain diiringi dengan jundai, juga diiringi dengan alat musik serunai dan rebana, yang maknanya yaitu akan menyatukan keluarga dengan orang baru sehingga membentuk keluarga baru. Menurut bapak YB ada sebuah seni suku Serawai yang penarinya haruslah ada dasar ilmu pencak silat.Tarian yang dimaksud ialah tari Napa.Napa tidak dilaksanakan di dalam rumah tetapi di luar rumah pada saat menyambut tamu kebesaran atau orang-orang terhormat salah satunya menyambut raja dan ratu sehari.Tari Napa merupakan sebuah tarian yang berasal dari gerakan pencak silat.Pencak silat itu gunanya untuk membela diri misalnya ketika dipukul.Dalam pelaksanaannya adalah antara 2 (dua) orang kesatria atau pendekar yang sedang beradu ketangkasan sebab didalam tarian itu ada gerakan pukul, tangkis, tangkap, serang dan menghindar.Tetapi pada saat pelaksaannya tidak boleh saling kena atau mengenai, nah jika kena itu namanya bulus.Perangkat yang harus ada dalam tradisi adat tari Napa yang sesungguhnya adalah 2 (dua) buah tikagh ghumbai dan diletakkan lengguai di atas tikar pas di tengah-tengah tikagh atau tikar.

\section{- Inti Gerak Tari Napa}

Menurut bapak IN, secara adat sebetulnya tari Napa ada 2 (dua) macam yaitu, tari Napa tangan kosong, dan tari Rendai yaitu tari Napa yang menggunakan pisau, atau pedang asli bukan properti. Tari Napa tangan kosong ialah tarian Napa tanpa menggunakan senjata seperti pisau, dan pedang.Tari Rendai (pisau) ialah tarian yang menggunakan pisau kecil yang dipakai saat pelaksanaan tari.Tari Rendai (pedang) ialah tarian yang menggunakan pedang yang dipakai di tengah-tengah pelaksanaan tari.Waktu penampilan tari Napa tidak dibatasi, tergantung penarinya atau semampu penari.Gerakan tari tangan kosong terdiri dari gerak tangan dan kaki yaitu ngancam, 
10 I Dwi Septi Fitriani

Makna Tari Napa Pada Bimbang Adat Suku Serawai Di Kota Manna .......

nangkap, dan ngunci, sedangkan gerakan kaki yaitu langkah tiga maju mundur atau mecah langkah (mengembangkan langkah).Tari Napa tidak mesti dilaksanakan dalam acara bimbang adat saja karena tari Napa juga untuk menyambut para tamu besar atau tamu kehormatan misalnya para pemimpin negeri, gubernur, bupati, camat, maupun raja dan ratu sehari.Sebelum melakukan tari Napa, kedua penari akan melakukan sekali gerak besembah atau penghormatan yang ditujukan pada raja dan ratu sehari dan sesudah melakukan tarian, kedua penari berjabat tangan sambil mengangkat tangan yang berjabat untuk diperlihatkan kesemua orang dengan makna perdamaian.

Tari Napa ditarikan oleh dua orang laki-laki yang saling berhadapan dengan gerakan pencak silat.Kedua penari selalu berhadapan karena memang sudah ketetapan.Lengguai atau tempat sirih selalu ada ketika tarian ini dilakukan, yang mana lengguai tersebut diletakkan di atas tikar yang biasanya terbuat dari anyaman ghumbai.Sesuai dengan asal-usulnya tarian ini merupakan gerakan pencak silat yang ditarikan sehingga lebih menarik.Tari Napa mempunyai gerak-gerakan sebagai unsur utama dan sebagai bahasa untuk komunikasi seperti menceritakan pertarungan dua orang yang saling beradu kekuatan tari, jadi agar tidak kalah dengan lawan ketenangan sangat dibutuhkan ketika bertarung.Dalam pelaksanaanya pun tidak ada urutan tetap pada Tari Napa, gerakan yang dipakai sesuai dengan kedua penari ketika menunjukkan tariannya.Menurut bapak YB gerakan tari Napa berikut maknanya dapat diuraikan sebagai berikut:

\section{a. Gerak Besembah}

Sebelum melakukan tari Napa, kedua penari akan melakukan sekali gerak besembah atau penghormatan yang ditujukan pada raja dan ratu sehari dan sesudah melakukan tarian, kedua penari berjabat tangan sambil mengangkat tangan yang berjabat untuk diperlihatkan ke semua orang dengan makna perdamaian.Posisi dari gerak besembah ialah dengan menekukkan kaki dengan setengah membungkukkan badan sambil menghadap ke arah raja dan ratu sehari kemudian mengangkat kedua tangan ke arah kepala dan menyatukannya, diangkat dan diletakkan kearah di depan wajah mengarah ke atas kepala, gerakan besembah ini bermakna bahwa penari memiliki sikap yang rendah diri dan menghormati, baik kepada diri sendiri, kepada orang lain kepada orang yang sedang dihormati pada saat itu. 


\section{b. Ngancam, Nangkap dan Ngunci (Gerakan Tangan)}

Ngancam atau mengancam ialah gerakan tari Napa seperti gerakan yang akan memukul seseorang ketika marah. Gerakan ini seperti mengangkat sebelah tangan ke atas untuk menggertak musuh dan meletakkan satu tangan lagi lebih rendah tepatnya di atas lutut untuk melindungi ketika musuh melakukan perlawanan. Gerakan ngancam ini mempunyai makna yaitu mengancam lawan atau musuh yang berniat akan mencelakakan. Nangkap atau menangkap ialah gerakan dalam tarian tari Napa yaitu dengan gerakan seolah-olah sedang hendak menangkap tangan musuh. Gerakan ini yaitu meletakkan salah satu tangan ke samping badan sambil diangkat seperti sedang bersiap untuk menangkap sesuatu dari musuh, kemudian tangan yang satunya diletakkan lebih rendah dari tangan yang diangkat tadi tapi agak jauh dari lutut dan diletakkan di samping badan seolah-olah akan menangkap sesuatu dari serangan musuh. Gerakan ngunci atau sedikit menggepalkan tangan dan meletakkannya ke arah pinggang seperti memegang sesuatu dengan teguh dan kuat, kemudian tangan yang satunya di arahkan ke musuh seolah-olah mengukur gerakan musuh dan kakinya yang kiri diletakkan ke depan untuk menyiapkan serangan apabila musuh menyerang dan mengunci serangan musuh dengan tangan yang sedikit di gepal tadi, dan kaki kanan diletakkan ke belakang sebagai tumpuan. Gerakan dalam tari Napa yang satu ini memiliki makna yang berarti memiliki pendirian yang teguh dalam kehidupan, pantang mundur dengan suatu keburukan, jika pun harus mundur kehormatan adalah harga mati.

\section{c. Mecah Langkah (Gerakan Kaki)}

Mecah atau mengembangkan.Langkah atau melangkahkan kaki.Mecah langkah artinya mengembangkan langkah kaki.Gerakannya yang pertama, maju yaitu maju dengan kaki kanan, maknanya ialah ketika melangkah hendaklah dimulai dengan kebaikan sebab kaki kanan merupakan simbol dari kebaikan.Kedua, mundur yaitu mundur dengan kaki kanan diletakkan ke belakang, maknanya ialah ketika memutuskan sesuatu hal haruslah dipikirkan dengan baik, sekalipun harus mundur tetapi demi menjaga kebaikan bersama. Ketiga, maju dengan kaki kiri diletakkan ke depan, maknanya ialah jangan pernah ragu untuk melangkah ke depan sekalipun harus tertatih. Keempat, kaki kanan yang di belakang diletakkan ke depan dan kaki kiri digeser diletakkan ke belakang maknanya ialah seperti pepatah "sepandai-pandainya tupai 
melompat pasti akan jatuh juga" artinya serapat dan setebal apapun penutup keburukan serta kebusukan hati manusia pasti akan diketahui juga, maknanya ialah kebaikanlah yang akan selalu berada di garis depan kehidupan.

\section{d. Bejabatan Tangan}

Bejabatan tangan atau berjabat atau bersalamantangan merupakan gerak penutup dalam tarian Napa.Gerak ini diakhiri dengan posisi duduk antara kedua penari.Gerakan ini diakhiri dengan duduk sambil bersalaman memiliki makna bahwa rendahnya hati kedua pendekar meskipun memiliki ilmu yang tinggi dan kuat.Bejabatan tangan ini menunjukkan simbol perdamaian antara kedua pendekar yang sebelumnya sudah beradu kekuatan. Kemudian, kedua penari sambil mengangkat tangan yang sedang bersalaman ke atas guna menunjukkan ke orang ramai sebagai bukti perdamaian mereka dan berakhirnya tarian Napa. Setelah para penari meninggalkan tempat menari acara selanjutnya diserahkan ke tиaи kerjau atau tua kerja atau ketua panitia.Ketika selesai melaksanakan tari Napa, barulah calon raja sehari beserta rombongan (mendah) masuk ke dalam rumah dengan didampingi oleh penghulu dan keluarga dari pihak calon ratu sehari untuk melakukan acara inti dari bimbang adat yaitu akad nikah dihadapan para saksi, dan selanjutnya sehari setelah akad nikah akan mengadakan pesta pernikahan atau peresmian pernikahan dan dalam bahasa Serawainya disebut bimbang adat yang mana calon raja dan ratu sehari sah menjadi raja dan ratu sehari dan menduduki singgasana atau pelaminan yang telah dipersiapkan oleh tuau kerjau.

\section{Bimbang Adat}

Setelah melaksanakan berbagai rangkaian acara sampai ke akad nikah secara adat, masuklah ke acara pesta yaitu bimbang adat. Bimbang adat ialah yang suatu upacara perkawinan adat hingga acara peresmian perkawinan dalam adat suku Serawai di Kota Manna, Kabupaten Bengkulu Selatan. Segala kegiatan dalam rangka upacara peresmian perkawinan berdasarkan yang telah ditetapkan dan yang telah musyawarah dari hasil beijau terutama oleh kedua belah pihak keluarga calon raja dan ratu sehari serta disetujui oleh ketua adat dan penghulu. Perlunya persetujuan kedua belah pihak keluarga calon raja dan ratu sehari, agar lebih mudah mengatur acara peresmian dan setiap kegiatan yang dilakukan baik di rumah mempelai perempuan ataupun di rumah mempelai laki-laki. Sebelum menjelang bimbang adat atau perayaan perkawinan di 
kedua belah pihak mengalami kesibukan, menghadapi bimbang.Dalam hal ini peneliti tidak menjelaskan secara jelas tentang bimbang adatnya karena fokus penelitian adalah tari Napa.

\section{Unsur-unsur Tari Napa}

\section{- Tuau Kerjau}

Tuau kerjau ialah orang yang dianggap penua yang dipercayai oleh tuan rumah untuk mengatur jalannya acara pada saat bimbang adat. Tuau kerjau mengatur jalannya acara yang biasanya dipilih pada saat prosesi beijau dalam majelis.Setelah terpilihnya tuau kerjau mulailah dia mengatur jalannya acara dari saat selesai beijau sampai dengan pesta pernikahannya.Biasanya tuau kerjau ini ada 2 (dua) orang yaitu, 1 (satu) orang tuau kerjau laki-laki dan 1 (satu) tuau kerjau perempuan.Tuau kerjau laki-laki adalah dia yang mengurus dan mengatur kegiatan yang dikerjakan oleh kaum laki-laki dan tuau kerjau perempuan adalah dia yang mengurus dan mengatur kegiatan yang dikerjalan oleh kaum perempuan.

\section{- Penari}

Dalam pelaksanaan tari Napa dilakukan antara 2 (dua) orang penari kesatria atau pendekar yang sedang beradu ketangkasan.Dilakukan paling sedikit 2 (dua) pasang dan paling banyak 4 (empat) pasang penari.Penari haruslah laki-laki sebab didalam tarian itu ada gerakan pukul, tangkis, tangkap, serang dan menghindar.Tetapi pada saat pelaksaannya tidak boleh saling kena atau mengenai, nah jika kena itu namanya bulus.Bulus adalah denda karena para penari saling mengenai dan tuan rumah tempat acara harus membayar denda dengan segera yaitu 3 (tiga) jambar, jika tidak dibayar maka para tamu undangan yang hadir akan meninggalkan tempat acara secara tidak hormat. Ketentuan jambar yang dibuat dan menjadi kewajiban itu ada 3 (tiga) macam, yaitu antara lain jambar nasi kunyit sebanyak tiga buah sebagai denda atas pemakaian tari Napa, jambar nasi lemak, jambar ini tidak ditentukan berapa banyaknya, hanya mengikuti kemampuan tuan rumah yang mengadakan acara, dan terakhir adalah jambar denda kepada orang yang melakukan kesalahan di dalam arena itu, yaitu harus nasi kunyit yang dibuat oleh sepokok rumah dengan porsi sesuai dengan jumlah orang yang berbuat kesalahan. Kemudian, orang yang berhak menerima jambar wajib, yang berupa 
nasi kunyit yang berjumlah 3 (tiga) buah yaitu yang bernama gerak alam (ketua adat/pemangku adat), melinggang alam (penghulu), dan getar alam (lurah/kepala desa).

Para penari ialah mereka yang sudah memiliki bekal pencak silat.Karena gerakan tari Napa merupakan gerakan pencak silat.Tentunya gerakan ini harus pakai tenaga, pada saat penari menarikan tarian ini tampak seperti tidak menggunakan tenaga, tetapi padahal tenaga yang dibutuhkan dalam gerakan tarian ini sangatlah menjadi hal penting.Biasanya saat selesai menari, para penari Napa berkeringat yang cukup banyak.Hal itu menunjukkan bahwa tarian ini tidak pantas apabila ditarikan oleh perempuan.Menurut bapak YB, zaman sekarang ini sudah banyak orang yang mengaku pandai menari Napa padahal tidak ada landasan dalam pencak silat.Penari yang memang berpengalaman dalam dunia persilatan tentunya gerakan tidak kaku, dan kelihatan pada saat menari Napa. Penari Napa dilakukan oleh seseorang yang memang ahli dalam silat namun dalam proses pelaksanaanya ditarikan oleh laki-laki yang sudah berusia lebih dari 30 tahun, dan sangat jarang penari tari Napa dari kalangan anak-anak muda.

Di Kota Manna, Kabupaten Bengkulu Selatan, bisa siapa saja yang ingin menjadi penari Napa asalkan ada satu syarat yang harus dipenuhi yaitu dia harus belajar pencak silat Serawai.Ketika seseorang hendak belajar pencak silat Serawai maka dia harus menemui calon pelatihnya.Dalam hal ini, bapak IN selaku pengurus Sanggar Maju Jaya juga merupakan pelatih pencak silat Serawai. Bagi siapa yang hendak belajar pencak silat Serawai, maka harus mengadakan jambaryaitu nasi kunyit dan menyerahkannya kepada beliau. Maknanya ialah untuk pamit kepada guru agung bahwa akan mengajari sianu untuk belajar silat tradisi Serawai. Sehingga orang yang belajar dipersilahkan untuk belajar pencak silat hingga selesai.Tandanya telah selesai belajar pencak silat ialah mengadakan jambar lagi di rumah pelatih.

\section{- Pemusik}

Dalam tari Napa pemusik atau penabuh iringan menjadi unsur yang juga sangat penting. Tanpa musik tarian seperti taman tak berbunga. Dalam tari Napa musik yang dimainkan ada 2 (dua) macam alat musik yaitu 2 (dua) buah rebana/gendang dan 1 (satu) buah serunai. Berdasarkan wawancara dengan bapak ME tari Napa dilaksanakan setelah bedindang.Karena jika tidak dilakukan bedindang, maka tari Napa tidak bisa dilaksanakan.Bedindang adalah memainkan alat musik, adapun alat atau instrument yang dipakai dalam dendang ini adalah rebana secukupnya, gendang 2 (dua) buah dan 1 
(satu) buah serunai.Setelah bedindang, barulah menari dan diiringi dengan musik rebana dan serunai.

\section{- Makna Sarana Tari Napa}

Menurut bapak YB selaku Ketua Badan Musyawarah Adat.Perangkat/sarana yang harus ada dalam tradisi adat tari Napa yang sesungguhnya adalah 2 (dua) buah tikagh ghumbai dan diletakkan lengguai di atas tikar pas di tengah-tengah tikagh.Tikagh (tikar) yang harus digunakan saat tari Napa ini adalah 2 (dua) tikar yang dibentuk tanda tambah. Tikar yang diletakkan ini memiliki makna pertemuan antara dua keluarga besar raja dan ratu sehari yang akan bersatu menjadi keluarga baru. Lengguai bagi suku Serawai dianggap sebagai raja adat.Lengguai itu diletakkan di atas tikar untuk tempat tari Napa dilakukan. Lengguai ini juga sebagai batas yang tidak boleh dilewati oleh kedua penari Napa Isi lengguai adalah perlengkapan sirih yaitu daun sirih selembar beserta tangkai, kapur sirih, daun gambir selembar, isi buah pinang dan masak serta tembakau.

\section{a. Tikar}

Tikar yang harus digunakan saat tari Napa ini adalah 2 (dua) tikar rumbai yang berasal dari daun pandan diletakan seperti tanda tambah atau seperti tanda silang.Diletakkan di luar rumah atau halaman rumah tempat dilaksanakannya tari Napa. Kemudian, tikar yang diletakkan seperti tanda tambah atau bersilang ini memiliki makna pertemuan antara dua keluarga besar yang akan bersatu menjadi keluarga baru.

\section{b. Lengguai}

Lengguai ini digunakan sebagai tempat untuk menaruh sirih yang dipakai apabila ada pertemuan yang menyangkut adat.Lengguai bagi suku Serawai dianggap sebagai raja adat.Setiap mau memulai serangkaian kerja adat maka harus dimulai dengan menyerahkan lengguai terlebih dahulu. Saat iringan calon raja sehari bersama mendah/tamu adat telah sampai di depan jalan sepokok rumah bimbang adat atau di lokasi bimbang adat atau lebih tepatnya di rumah calon ratu sehari dengan membawa lengguai, maka lengguai yang tadinya berada dihadapan ketua adat/tokoh yang menyambut kedatangan mendah tadi harus dihadapkan terlebih dahulu pada rombongan mendah tersebut yang membawa sebagai tanda lengguai tersebut telah diterima oleh ketua adat/tokoh adat yang menunggu dilokasi. Setelah diterima, lengguai itu diletakkan di atas tikar untuk tempat tari Napa dilakukan. Lengguai ini juga sebagai 
batas yang tidak boleh dilewati oleh kedua penari/kesatria/pendekar Napa yang sedang bertarung. Isi lengguai ini terdiri dari daun sirih, kapur, pinang, gambigh (gambir) dan tembakau. Makna dari isi lengguai ini adalah:
a. Sirih bermakna lambang adat
b. Kapur bermakna bersihnya kerja adat
c. Gambigh (gambir) bermakna lapiak, lakup/tikar tempat duduk raja adat
d. Pinang sebagai tonggak raja adat
e. Tembakau adalah pengarang lembaga adat

\section{- Makna Kostum Tari Napa}

Kostum merupakan segala sandang dan perlengkapan yang dikenakan penari diatas panggung. Tari Napa merupakan tarian yang berpasang-pasangan antar sesama laki-laki sehingga kostum yang dipakai sama. Menurut bapak YB selaku Ketua Badan Musyawarah Adat kostum laki-laki berupa baju pengantin laki-laki atau baju raja sehari atau paling tidaknya memakai baju kemeja panjang bebas warna dengan ditutuipi jas warna hitam, celana dasar bewarna hitam dan kopiah berwarna hitam. Biasanya yang memakai pakaian ini hanyalah seorang raja sehari atau pengantin laki-laki, maka penari pada umumnya bisa memakai kostum seperti baju kemeja panjang, jas warana hitam, celana panjang warna hitam, kain sarung dan kopiah warna hitam, meskipun kostumnya agak berbeda dengan pengantin laki-laki maknanya tetaplah sama.

\section{a. Baju Kemeja Panjang}

Baju kemeja panjang melambangkan kewibawaan seorang pendekar.Ketika seorang laki-laki memakai baju kemeja panjang biasanya tampak seorang laki-laki yang tegas dan bijak. Sebab seorang pendekar adalah sosok orang yang tegas, tegar, kuat dan patut untuk dijadikan seorang pelindung,

\section{b. Jas Warna Hitam}

Jas warna hitam melambangkan kematangan dan kebijaksanaan.Suku Serawai menganut paham patriaki di mana laki-laki dianggap pemegang kekuasaan utama dan mendominasi dalam peran kepemimpinan. Jas warna hitam dalam tarian Napa bermakna bahwa laki-laki dalam suku Serawai harus memiliki jiwa bijaksana sebagai seorang pemimpin yang nantinya paling tidak tentu akan menjadi pemimpin dalam kepala keluarga dan mungkin juga akan menjadi pemimpin dalam masyarakat. 


\section{c. Celana Dasar Warna Hitam}

Celana dasar warna hitam sebagai simbol kematangan. Artinya para pendekar merupakan laki-laki yang sudah berusia, dengan masa usianya itu perkembangan sosial harus mampu berkembang dan dikembangkan dalam memahami orang lain sebagai individu yang unik baik menyangkut sifat-sifat pribadi, nilai-nilai atau perasaan sehingga mendorong masyarakat untuk bersosialisasi dan lebih akrab dengan lingkungannya sesuai dengan tari Napa bahwa tarian ini dibawakan oleh para pendekar.

\section{d. Kain Sarung}

Dalam adat Serawai pada saat menari Napa ialah memakai sarung dengan bentuk “tetak gendang”.Namun, seiring berkembangnya zaman dan dengan masuknya budaya luar sehingga kain sarung yang semulanya dipakai “tetak gendang”. Salah satu hal yang menyebabkan pemakaian kain ada yang tetak gendang dan ada yang tidak ialah kurangnya pengetahuan bagi masyarakat tetang budaya Serawai. Kain sarung sebagai simbol kesopanan dan bermakna apabila digunakan seorang penari akan terhindar dari bahaya, gangguan roh jahat dan selalu dalam perlindungan Tuhan Yang Maha Esa. Kain sarung juga sebagai media memperindah penampilan para penari.Dengan menggunakan kain sarung para penari/kesatria/pendekar terlihat gagah dan terlihat sopan.Motif kain sarung yang digunakan juga tidak terlalu ditentukan.Menurut bapak YB setiap laki-laki yang memakai sarung berarti dia memegang teguh nilai-nilai kesopanan.Baik di dalam rumah, maupun saat mendatangi acara bimbang adat terlebih lagi dalam majelis dan menari tari Napa.

\section{e. Kopiah Warna Hitam}

Kopiah warna hitam maknanya laki-laki dalam suku Serawai mampu bersikap dengan baik, mengambil keputusan secara tepat karena laki-laki adalah harapan bagi perempuan, bagi keluarga untuk kelangsungan hidup yang lebih baik.

\section{Analisis Makna Tari Napa Pada Bimbang Adat Suku Serawai Berdasarkan Teori Interaksionisme Simbolid George Herbert Mead}

Menurut Mead menjelaskan dalam suatu sistem budaya dapat ditemui empat perangkat simbol yang masing-masing mempunyai fungsi tersendiri bagi manusiamanusia yang bersangkutan dalam tindakan antara mereka .Keempat perangkat simbol tersebut yaitu : 
1. Simbol-simbol Konstitutif yang berbentuk sebagai kepercayaan-kepercayaan. Sama halnya makna simbolik tari Napa rangkaian sarana tari Napa seperti jambar dan lengguai bahwa hal tersebut adalah bentuk kepercayaan masyarakat kepada kepercayaan mereka berupa roh guru agung sebagai simbol permohonan pamit dan permohonan agar diberi kelancaran dan keamanan dalam melaksanakan pembelajaran atau menurunkan ajaran pencak silat Serawai. Sarana tersebut adalah bentuk komunikasi masyarakat Serawai kepada kepercayaan mereka.

2. Simbol -simbol penilaian moral yang membentuk aturan-aturan dan nilai-nilai. Sama halnya pada rangkaian tari Napa, simbol-simbol dari prosesi tari Napa mengajarkan bahwa mengandung nilai-nilai moral seperti simbol-simbol jambar yang mengandung pesan sosial yang diajarkan oleh para tetua suku Serawai yang harus dipatuhi.Pesan sosial berupa ajaran untuk berbuat baik, menjaga persaudaraan dan ikatan silaturahim, serta menjunjung nilai persatuan dan lain-lain.

3. Simbol-simbol pengungkapan perasaan. Seperti pada gerakan-gerakan tari Napa mengandung simbol pengungkapan perasaaan.Seperti ungkapan bahwa mampu membela diri, baik membela diri dalam melindungi diri sendiri maupun orang lain, dan juga melindungi segenap perangkat adat baik budaya maupun adat istiadat dari celaka.

4. Simbol-simbol kognitif yang membentuk Ilmu pengetahuan seperti pada rangkaian tari Napa, simbol-simbol tersebut memberikan pengetahuan kepada masyarakat Serawai mengenai nilai-nilai kehidupan. Melalui simbol simbol lengguai beserta isinya seperti sirih, gambir, buah pinang, tembakau, dan kapur yang digunakan pada tari Napa, merupakan pengetahuan bahwa masyarakat Serawai dalam kemakmuran, melimpah sumber daya alam. Seperti simbol lengguai berupa sirih, gambigh atau gambir, buah pinang, tembakau, dan kapur merupakan ilmu pengetahuan untuk mencapai kehidupan yang baik.

Manusia pada hakikatnya adalah makhluk yang selalu melakukan interaksi. Terkadang manusia seperti halnya masyarakat Serawai dalam interaksi sosialnya melalui tari Napadisadari atau tidak menampakkan fenomena yang berupa simbolsimbol dan mempunyai banyak pemaknaan dalam simbol-simbol tersebut, hal ini merupakan refleksi dari fenomena Interaksionisme Simbolik. 


\section{KESIMPULAN}

Hasil penelitian menunjukkan bahwaTari Napa ada 2 (dua) jenis yaitu tari Napa yang menggunakan pedang atau pisau asli bukan properti yang disebut tari Rendai, dan tari Napa tangan kosong.Dalam penelitian ini fokus pada tari Napa tangan kosong. Tari Rendai dan tari Napa mempunyai gerakan yang sama. Tari Napa tidak hanya dilaksanakan pada acara bimbang adat saja tetapi juga dilaksanakan pada saat acara pemerintahan penyambutan para pemimpin negeri seperti yang telah dijelaskan di atas.Dalam hal ini, fokusnya pada acara bimbang adat suku Serawai.Tari Napa ditarikan oleh dua orang laki-laki yang saling berhadapan dengan gerak menyerupai pencak silat.Tari Napa dimulai dengan bedindang.Pelaksanaan tari Napa pun selain diiringi dengan jundai, juga diiringi dengan alat musik serunai dan rebana.

\section{DAFTAR PUSTAKA}

Alwi, Iskandar Z. 2003. Pasar Modal, Teori dan Aplikasi. Jakarta: Nasindo Internusa.

Bahri, Aditia Syaeful. 2015. Pertunjukkan Kesenian EBEG GRUP MUNCUL JAYA Pada Acara Khitanan di Kabupaten Pangandara. Bandung: Universitas Pendidikan Indonesia. Dari sumber website http://repository.upi.edu/20430/5/S_SM_0900029_Chapter2.pdf.diakses pada tanggal 21 Agustus 2018.

Djafar, Nurlia. 2014. Simbol dan Makna Tari Langga Buwa Karya Muraji Bereki. Jurnal.Program Penciptaan dan Pengkajian. Pascasarjana Institut Seni Indonesia Yogyakarta.Dari sumber website http://digilib.isi.ac.id/846/1/BAB\%20I\%20Nurlia.pdf.diakses pada tanggal 11 Oktober 2018.

Emzir. 2005. Metode Penelitian Kualitatif. Jakarta : Rajawali Pers.

Fretisari, imma.2016. Makna Simbol Tari Nimang Padi Dalam Upacara Adat Naek Dango Masyarakat Dayak Kanayant.Jurnal. Universitas Tanjungpura. Dari sumber $\quad$ website https://journal.unnes.ac.id/sju/index.php/jst/article/view/9620/6127.diakses pada tanggal 11 Oktober 2018.

Haryani, Oktariana. 2013. Kesenian Safaral Anam dan Nilai-nilai Yang Terkandung di Dalamnya Pada Masyarakat Lembak Dalam Adat Istiadat. Skirpsi. Universitas Bengkulu. Jurusan Sosiologi. Fakultas Ilmu Sosial dan Ilmu Politik.

Herimanto dan Winarno.2008. Ilmu Sosial dan Budaya Dasar.Jakarta Timur.BumiAksara. 
Makna Tari Napa Pada Bimbang Adat Suku Serawai Di Kota Manna .......

Indra.2012. Kesenian, dalam http://panjiindra2345.blogspot.com/2012/10/pengertiankesenian_23.html.28/03/2018.

Junita. 2013. Tari Napa Di Kecamatan Kota Manna Kabupaten Bengkulu Selatan.darisumber website: http://download.portalgaruda.org/article.php?article=101246\&val=1538. Diakses pada tanggal 27 Juli 2018.

Koentjaraningrat. 2009. Kebudayaan Mentalisdan Pembangunan. Jakarta: Gramedia Pustaka Umum. 2009. Pengantar Ilmu Antropologi. Jakarta. Rineka Cipta.

Kusumawardani, ida. 2013. Makna simbolik tari sontoloyo giyanti kabupaten Wonosobo. Jurnal. Jurusan Sendratasik. Fakultas Bahasa dan Seni.Universitas Negeri Semarang.Dari sumber website https://journal.unnes.ac.id/sju/index.php/jst/article/view/9620/6127.diakses pada tanggal 11 Oktober 2018.

Maran, Rafael Raga. 2007. Manusia dan Kebudayaan Dalam Perspektif Ilmu Budaya Dasar. Jakarta: Rineka Cipta.

Nahari, Dian Solihati Aji. 2017. Pelaksanaan Kegiatan Seni Tradisional Yang Islami.Purwokerto: FKIP UMP. Dari sumber website http://repository.ump.ac.id/3554/3/BAB\%20II.pdf.Yang diakses pada tanggal 21 Agustus 2018.

Piet. 2017. Seni Pertunjukkan Kuda Kepang Pada Masyarakat Rejang. Skripsi. Universitas Bengkulu. Jurusan Sosiologi. Fakultas Ilmu Sosial dan Ilmu Politik.

Rahmawati Setiawati. 2008. Seni Tari. Jakarta: Direktorat Pembinaan Sekolah Menengah Kejuruan, Direktorat Jendral Manajemen Pendidikan Dasar dan Menengah, Departemen Pendidikan Nasional.

Ranjabar, Jacobus. 2013. Sistem Sosial Budaya Indonesia. Bandung: Alfabeta.

Ritzer, George, Douglas J. Goodman.2013. Teori Sosiologi Dari Teori Sosiologi Klasik sampai Perkembangan Mutakhir Teori Sosial Postmodern.Bantul : Kreasi Wacana.

Ritzer, George. 1992. Sosiologi Ilmu Pengetahuan Berparadigma Ganda. Jakarta. Rajawali Pers.

Sugiyono. 2005. Memahami Penelitian Kualitatif. Bandung: Alfabeta.

Sugiyono. 2010. Metode Penelitian Administrasi. Bandung : Alfabeta. 2012. Metode Penelitian Kualitatif. Bandung: Alfabeta. 
Sumaryono. 2011. Antropologi Tari. Yogyakarta: Badan Penerbit Institut Seni Indonesia Yogyakarta.

Wulansari, C, Dewi. 2013. Sosiologi Konsep dan Teori. Bandung: Refika Aditama.

Yuanita, Alfia Puji. 2010. Kearifan Lokal Tari Gandrung dan Upaya Pelestariananya di Desa Kemiren, Kecamatan Glagah, Kabupaten Banyuwangi.Skripsi. Fakultas Ilmu Sosial Universitas Negeri Malang 